\title{
Creating "SMART” Supply Chain Scenarios Using SAP R/3
}

Joseph M. Ragan, (Email: jragan@sju.edu), Saint Joseph’s University

Patrick J. McGettigan, Saint Joseph's University

Michael R. Storms, Saint Joseph's University

Brian Rizman, Saint Joseph's University

\begin{abstract}
Pedagogical revisions to the undergraduate Haub School of Business curriculum at Saint Joseph's University employing the SAP R/3 system encompass the core accounting courses traversing the sophomore and junior years. The entire accounting curriculum was overhauled in order to integrate SAP R/3. Each course progressively builds upon and expands the knowledge base in the prior course(s). Substantive pedagogical modifications have been integrated into the material delivered and methodologies utilized in selected sections of the required sophomore and junior accounting courses. SAP supported material, created and modified by a student team, is delivered in the classroom using a team-oriented format within a business case context. It is envisioned that the SAP material will seamlessly present accounting issues currently in the curriculum, while allowing the students to observe the capabilities of SAP R/3. This paper discusses the design, implementation, and execution of collaborative supply chain business scenarios using $S A P R / 3$ as the platform. Its use within an undergraduate curriculum is assessed and evaluated. Sample scenarios and a demonstration case are included.
\end{abstract}

\section{Introduction}

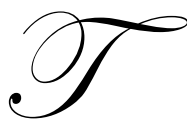

he Accounting Curriculum at Saint Joseph's University has undergone an extensive renovation over the last several years, in an attempt to become a more forward-looking, technology based department, with an advanced curriculum aimed toward providing value-added Accounting Information System (AIS) exposure. The Accounting Department has employed SAP R/3 as its model AIS, and has done so because of SAP's substantial market share and revolutionary integrated systems approach. The focus of the integration of SAP-based scenarios has been applied to mainly sophomore and junior level accounting courses. The scenarios used were created and modified by a team of highly qualified and motivated students, one of the main reasons why the curriculum renovation has been so successful.

The delivery of SAP scenarios within an accounting classroom is through a business case context. Throughout the semester, students are slowly exposed to SAP, beginning with simple Navigation and progressing up to Production Planning and Accounting and Reporting. The course then concludes with a student team project, which demonstrates their knowledge of Supply Chain Management and its importance within an accounting context. The SAP scenarios themselves are taught using the "SMART" approach. SMART is an acronym standing for: Structure, Master file, Application process, Reports, and Test of internal controls. This approach follows the process by which each module of the Supply Chain in SAP is oriented around. By stressing the importance of this structured approach, students are more able to grasp the complexities and intricacies of the SAP system, making it easier to apply a pedagogical understanding of its importance to an undergraduate accounting major. Appendix A represents how "SMART" is applied to the Supply Chain Scenario.

The future of accounting will revolve around technology. This neo-accounting idea is being grasped by Saint Joseph's University in its continued effort to provide its students with the most progressive curriculum available to them. As students proceed into a real-world accounting atmosphere, the skills they have developed 
through the use and knowledge of an AIS Supply Chain will greatly help their ability to attain post-graduate employment and provide serviceable skills to their employers.

\section{Background and Prior Research}

Albrecht and Sack (2000) paint a dismal portrait of the academic accounting profession as a discipline stuck in the past and exhibiting an unwillingness to change. They observe that technological innovation has rendered the gathering and reporting of information as an inexpensive process in today's environment. Accountants must be armed, they propose, with new skills if they are to find a role in today's environment. They suggest that accounting educators should embrace the unfolding Internet revolution and include this experience as an integral part of the pedagogy of accounting education.

Accounting professionals also recognize this revolutionary change, and promote the implementation of higher technology for business processes. The AICPA (2000b) has made Internet usage one of its top ten technologies for the start of the new century. When professionals were asked what skill other than financial expertise was most critical for success in the accounting discipline, the overwhelming choice was Internet technology (AICPA, 2000a). Educational organizations, such as the Federation of Schools of Accountancy (1999), have offered strong recommendations for specific actions that might be taken by today's universities in an effort to improve technology education. Greater reliance on the Internet is one of the cornerstones of such proposals.

The overall conclusion to be drawn from recent literature geared toward technological integration is that the current level of exposure accounting students has to Internet-related technologies is too limited. Tuteja (2000) notes that ERP software applications are expensive and may strain the budgets of academic departments who attempt implementation. Stedman (1999) determined that as colleges and universities adopted ERP applications for their own organizational management uses, they found a "secret resource" for use in the classroom. In customizing this type of system for classroom applications, some educational institutions seem to have found a unique way to attract students back to the classroom. Becerra-Fernandez, Murphy, and Simon (2000) note that demand for trained enterprise resource planning professionals has motivated a number of universities to join alliances with ERP software vendors such as SAP. The primary vehicle such vendors have to make their product work in the educational marketplace is through the Internet. Kaveney (2000) confirms that Internet capabilities enabled his own institution (Syracuse University) to substantially enrich both the curriculum and pedagogy in its business programs.

A particularly interesting point raised in literature deals with the roll of accounting as a business integrator. George and Asha (2002) see ERP as the perfect vehicle to teach the supply chain and since SAP is a monolithic Accounting Information System it serves well the effort to demonstrate integration through accounting. Volkoff notes (2003) that teachers are currently developing cases to give a concrete sense of what it means to configure and develop ERP based software. The benefits derived provide even the accounting students with a unique appreciation for the challenge of information delivery in the future. Chau and Chan (2002) see ERP as the perfect vehicle to teach continuous process improvement and enhance project decision making. Their paper further calls for a systematic implementation process incorporating the tools from ERP into the classroom. A Kirby (2002) note that ERP has essentially overcome all the implementation problems originally experienced and is now the vital engine by which key information is generated for the modern business. Roby, Ross, and Boudreau (2002) reports that schools are now attempting to teach integration with the use of ERP based technologies to enhance the placement of students and build stronger core skills and consulting capabilities within their students.

The issue for study, then, is how academic accountants, the educators of future professionals, should and should not use this ERP technology to educate. The first task was choosing which version of ERP to use. SAP R/3 was chosen because it has a formal University Alliance Program, of which we are a member. As a member, we receive the full ERP suite, which includes 12 major modules including forecasting, production planning, and material requirement planning areas. To date, St. Joseph's University has received over $\$ 100,000$ in grants to test implementation of SAP in the classroom. 


\section{IDES: A Sample Case}

IDES Database is a training database set up by SAP. The IDES group comprises four areas: IDES industry, IDES retail, IDES services, and IDES banking. Each of these areas consists of subgroups, which in turn consist of separate companies. The IDES Industry area comprises, for example, the subgroups IDES Europe, IDES America, and IDES Asia. Each of these subgroups consists of separate companies.

Every one of these companies has a clear-cut business task within the corporate group. Furthermore, each company is organized in accordance with the legal and country specific requirements of the country in which it is situated. Within the companies the IDES industry area, industry-specific sales, production, purchasing and accounting processes are presented. The American and German companies are, for example, defined as producing entities. The French subgroup is solely a sales and marketing entity, whereas the Mexican subsidiary is used to show what the materials ledger looks like in countries with high inflation rates. The Retail Area consists of commercial companies residing in the U.S. and Germany, which in turn are divided into other concerns. All common commercial processes are shown here. IDES Service illustrates a consulting company residing in America; here consulting services, amongst other things, are sold, delivered, and have their return assessed. The IDES banking area consists of two banks residing in the U.S. and Germany.

\section{The IDES Organizational Structure}

Logistics

A variety of products are manufactured and sold using different organizational units within the Logistics area. IDES provides all the resources required for production and assigns them to the corresponding products through bills of materials (BOMs) and routings. Each product or product group represents a particular production type. IDES contains fully-integrated business processes for the production or sale of the following products or product groups:

\begin{tabular}{|c|c|}
\hline Product & Process Type \\
\hline Motorcycles & Make-to-order production \\
\hline Cars & Sales-order-based repetitive manufacturing \\
\hline Pumps & Make-to-order production \\
\hline Personal computer & Repetitive manufacturing \\
\hline
\end{tabular}

The IDES system can be used to create personal prototypes for business processes. Once familiar with the SAP System business processes, IDES can be adapted to meet any specific individual requirements. The IDES enterprise structure helps create business scenarios that reflect individual working environments. It is possible to then implement core business processes for specific companies and analyze the various solutions. IDES also offers the additional advantage that it is not necessary to start from scratch each time a new company is created. The existing IDES system and its processes can be used as a basis, and organizational units and master data then simply be added until a new, personalized business process has been created.

\section{Organization}

\section{External organizations}

IDES has two sales organizations in Germany:1000 (Frankfurt) and 1020 (Berlin) and two in the United States: 3000 (Philadelphia) and 3020 (Denver). The products and services marketed are clearly allocated to one division and reach the customer via different distribution channels. 


\section{$\underline{\text { Sales Organizations }}$}

The sales organizations have the following areas of responsibility:

- Sales organizations 1000 and 3000 are in charge of selling and distributing pumps, elevators, lighting, motorcycles, vehicles, and high tech products.

- Sales organizations 1020 and 3020 are responsible for consumer goods, chemical and pharmaceutical products and cosmetics.

$\underline{\text { Sales Divisions }}$

Material and services sold in IDES are allocated to the following product divisions:

\begin{tabular}{|c|c|}
\hline Division & Description \\
\hline 01 & Pumps \\
\hline 02 & Motorcycles \\
\hline 07 & High Tech \\
\hline 08 & Services \\
\hline 10 & Vehicles \\
\hline
\end{tabular}

Distribution Channels

The sales of IDES products takes place via the following distribution channels:

\begin{tabular}{|c|c|}
\hline Distribution Channel & Description \\
\hline 10 & End customer sales \\
\hline 12 & Sold for resale \\
\hline 14 & Service \\
\hline
\end{tabular}

Sales Areas

The materials that are managed in each organizational unit are determined by the sales area, that is, the combination of a sales organization, a distribution channel, and a division. Sales in IDES are carried out on a cross-divisional basis via division 00 .

Sales documents in IDES are processed in one of the following sales areas:

\begin{tabular}{|c|c|c|}
\hline Sales Organization & Distribution Channel & Division \\
\hline 1000 & 10 & 00 \\
\hline 1000 & 12 & 00 \\
\hline 3000 & 10 & 00 \\
\hline 3000 & 12 & 00 \\
\hline
\end{tabular}


All other divisions are assigned to the different products (product division) and play a key role in the following processes:

- $\quad$ Business area determination in the sales document.

- Data update in the Sales Information System (SIS) and in Profitability Analysis (CO-PA).

To simplify, we will limit our discussion to developing scenarios in 3000 plant (US).

\section{Production}

Production of pumps and motorcycles in Plant 3000 takes place in a "make-to-stock; production environment. Production activities are performed in work centers that are assigned to production cost centers. The company has created material masters, a bill of materials and a routing for a pump and its sub-components, which define the material and labor involved in producing pumps. Monthly production quantities of pumps are planned using Master Production Scheduling (MPS) based on a monthly sales plan and target inventory levels specified in Sales Operations Planning (SOP). Planned monthly production quantities of finished products are translated into corresponding sets of planned purchase orders for raw materials and planned production orders using Material Requirements Planning (MRP). The planned monthly production orders also imply a corresponding set of planned monthly quantities for the various activity types, which will be executed in work centers within each production cost center.

Plant 3000 uses a set of standard costs to charge out its production of pumps. These standard costs are maintained within the "controlling" module.

Procurement and Vendors

The company continually searches for new vendors that might supply the necessary raw materials and components that are needed to produce pumps. In addition, the company purchases a variety of other goods and services needed by its various cost centers. Products purchased from a vendor use storage Location 0001 and Plant 3000 .

\section{Financial Accounting}

Company code 3000 uses chart of accounts CAUS (chart of accounts-United States) and currency USD (U.S. dollar). The company's fiscal year is based on the calendar year, which is divided into 12 monthly reporting periods. The company prepares planned monthly income statements and compares planned to actual results at the end of each month.

Financial accounting maintains "accounting" views of various master records, including customer masters, vendor masters, and material masters.

\section{Controlling}

Controlling area 2000 uses the same chart of accounts (CAUS), currency (USD) and fiscal year as company code 3000. As indicated earlier, company 3000 falls within IDES's controlling area 2000, which encompasses North America and Australia. This controlling area is broken down into cost centers. The company creates yearly financial plans for its various cost centers, which are broken down by month and are compared to actual results.

As part of cost center panning, plant 3000 determines the planned monthly amount of each activity type for its various production cost centers. These planned monthly activity quantities reflect planned production orders, and are the basis for computing planned activity prices, which are used in internal cost allocations and product costing. 
Periodically, plant 3000 revises its standard costs for raw materials, purchased components, subassemblies and final assemblies involving motorcycles and pumps. These revised standard costs are then introduced in the "costing" view of the various material masters and are used to compare variances related to production orders completed during the period.

\section{Profitability Analysis}

Within IDEA (IDES' reporting system), profitability analysis is conducted within an organizational unit called an "operating concern." IDEA uses only one operating concern, IDES, for its worldwide operations.

The IDES management team routinely examines the profitability (i.e., planned vs. actual results) of products and customers within its various "external" sales areas - i.e., by sales organization, sales channel, and sales division. Management also analyzes the profitability of these same products and customers from the standpoint of its "internal" sales organization - i.e., by sales district, sales office, and sales group. Management uses standard "performance" measures to assess profitability within the various segments of its "external" and "internal" sales organization. The company develops monthly plans for each of the above performance measures and compares planned to actual results on a monthly basis for each market segment.

\section{Profit Centers}

Controlling area 2000 is also divided into various profit centers that reflect internal assignments of management responsibilities. Profit centers reflect a product line breakdown and all of the profit relevant activities associated with pumps are assigned to profit center 3010 (High Speed Pumps). The IDES management team routinely examines the profitability of its various profit centers.

\section{The Supply Chain Processes using SMART}

\section{Purchase Order Management}

Every module in the supply chain requires a structure to be setup. Students at Saint Joseph's usually use company code 3000 (United States), which aside from client number is the highest defined structure in the SAP hierarchy. The students here have also used Company Code 1000 (Germany). The comprehensive supply chain begins with the student purchasing raw materials; this is completed through SAP's Purchase Order Management (POM) system, but before this can be done a vendor must be located and/or created in the system. A Vendor Master is how a vendor is created within the system. Vendor master records only need to be set up once (unless something changes with a vendor), but the students are required to do this in order for them to have their own personal vendor. Students are asked to customize the names of the master files they create, which adds some entertainment value to the exercise. Three types of vendor master records must be setup, Accounting, Purchasing, and an Information record. The Accounting records deal with the vendor's name, address (personalized by the students), reconciliation account, and the payment terms agreed upon, etc. The purchasing records define what currencies are used as well as the terms of payment again. Finally, the Information record assigns the vendor to a purchasing group and defines the quantity of product normally sold, the minimum quantity, and at what price.

Once a vendor is setup, raw materials can now be purchased. In order to do this the student must create a Purchase Order (PO). The PO is the Transaction file that runs the POM process. It contains what materials are being purchased, from whom they are being purchased, by whom, how many, and on what date. Once the PO is filed, the students are asked to check inventory for their material. No inventory will exist because the materials have not yet been received, so the student then tells the system that the goods have been received. They are then asked to check inventory again, and the materials can now be found in inventory. The first journal entry is triggered, which record the debit to inventory and credit to goods received. The students are asked to view this journal entry, and in doing so, are testing internal control for reliability and validity. 
All that is left, at this point, is to receive the vendor's invoice and pay the vendor. Once this is accomplished the POM process has been completed.

\section{Production Planning}

Production Planning is SAP R/3's heart and soul. It is SAP's greatest system, but also its most complex. Students are asked to build their own product from the raw materials they purchased in the POM process. The structure for PP typically used is Company Code 3000 (US) and Plant 3000 (New York).

A Material Master for the product that will eventually be produced must be created. This only needs to be done the first time a new product is going to be produced, but since the students are asked to create their own personal product (copied from an already existing product), they must complete this step in the process, thus giving them a broader view of what the supply chain encompasses. When setting up the Material Master, students are asked to personalize its name to give them more of a bond to their particular product. The students can create a number of products, such as motorcycles (the most popular), air pumps, and computers. Creating the Material Master is integral to the remainder of the supply chain process, as it is the master file for everything that will occur later. A mistake in the Material Master can create any number of problems throughout the supply chain process, and this fact is stressed to the students. The reason why the Material Master can cause so many problems is because it encompasses every aspect of the material being produced, and requires a number of inputs to be made dealing with everything from where and by whom it is produced to specific pricing information.

Once the Material Master is completed a Bill of Materials (BOM) must be put together. The BOM specifies what raw materials and sub-assemblies make up the students final product. Since the student's product is copied from an already existing product, most of the BOM is then also copied due to the complexity that can go into a BOM. The students are only asked to designate which sub-assemblies go into the product, thus showing them how to create a BOM without them having to dedicate a substantial amount of time into designing a BOM.

After the BOM is complete, the product must be routed. This step is relatively simple compared to the last two PP steps, and merely designates how the product will be released.

The next step is slightly more complex than the routing and it requires the students to create a production plan that will be sent to "demand" management. In creating a production plan, the students create what is referred to as a rough-cut plan. They are required to specify the number of sales that they expect and the target stock levels for the four months into the future. From this rough-cut plan, the students can then tell SAP to create a production plan. They are then asked to send the plan along to demand management. This step demonstrates an applications process within SAP.

The last production planning step that has to occur before a production order can be created is for the Materials Requirements Planning (MRP) to run. Running MRP helps to ensure the availability of the product, as well as it being completed in a timely manner in order for it to be ready for sale and distribution.

At this point, production planning has been completed and the transaction file that triggers the production process can now be created. To create a Production Order the students are asked to go to the stock requirements list, which is a representation of the production plan they created earlier. Creating a production order from here is as simple as clicking on the first planned order and pressing one button to turn it into a production order. The production order can be reviewed, which will tell the student the exact date and times that the product will be put together. Once the production order is released it must be confirmed. Since there is no actual production that results from the student's production order, they are asked to do what is called a 101 transfer. This tells the system that production has been completed for their order and that there is now inventory for the student's particular product. It can now be prepared for sale. 
Before beginning the sales process, however, the students are once again asked to review the journal entry that deals with their previous transaction. By doing this the students are shown how the Logistics module of SAP $\mathrm{R} / 3$ is integrated with the Accounting and Costing modules.

\section{Customer Order Management}

Just like the previous two modules, Customer Order Management (COM) requires that a company structure be defined. Again Company Code 3000 is used, as well as Sales Organization 3000, Distribution Channel 10, and Division 00. COM keeps all of a company's customers, products for sale, pricing structures, warehouse management, and billing administration in order.

With the right structure in place, the students are asked to create a Customer Master. This step is very similar to the creation of a Vendor Master in POM, with the obvious exception that this master is for selling instead of purchasing. Once again, the students have the ability to customize their customer. The Customer Master includes basic information, reconciliation accounts, terms of payment, delivery priorities, shipping conditions, incoterms, and tax applications.

After the Customer Master is created, the product the students produced in PP can now be sold to their new customer. This is done by creating a Sales Order. The structure is once again defined, and in the Sales Order it is specified as to who the product is being sold to, where it is being shipped, the date, what material is being sold, and how much it is being sold for.

Now that the Sales Order has been filed, the students must let the shipping department know that a delivery must be made. This is done by creating a delivery order, which involves entering a Shipping Point (what part of the world the product is going to), the required delivery date that the customer wishes to receive the product, as well as the amount of time the product can feasibly be prepared for shipment, and the sales order number. The students then need to tell the warehouse to pick the items off the shelves through the use of a transfer order. Once the goods are shipped, they can be posted as goods issued.

The last item of business is to create a billing document that is to be sent to the customer. As long as all of the previous documents were created correctly and the Customer and Material Masters were properly configured, creating a billing invoice is as simple as hitting a save button. The students are then required to review all accounting documents that are tied to the COM process.

\section{Student Projects}

Working in teams and individually, students execute a series of handout assignments involving the performance of the following major tasks:

\section{Customers}

Students create new customers for pumps that have a range of different characteristics (e.g., location, distribution channel, credit limits, etc.). These customers are then the focus of sales planning and profitability analysis.

Vendors

Students create new vendors and execute a variety of purchases involving raw materials, components, and other goods and services offered by their particular vendors. 
Product

Students create products of which the parts are purchased from the vendors and sold to the customers that they setup. Several steps are involved in the production process of their product:

Sales quantity plan

Students create a sales quantity plan for their product, broken down by market segment (e.g., customer, distribution channel, etc.)

Production quantity plan

Students create production quantity plan for their product and its various subassemblies.

Procurement plan

Students create procurement plan for the materials/components required for the planned production of pumps and its various subassemblies

Cost center plans

Students create cost center plans for the various cost centers-corporate services, finance and administration, procurement, marketing, and production (including planning of activity types the two production cost centers)

Profitability segment plans

Students create profitability segment plans for selected market segments

Recording Actual Results

Students record actual results for each month for sales, production, procurement, and cost center costs that are incurred.

\section{Conclusion}

The key expected deliverable of this project is a series of scripts utilizing SAP R/3 and Supply Chain Modules. Students were very receptive to testing application scenarios and working within the SAP System. On going development needs to refine the scripts and expand the scope of the modules. In surveying students we found great interest in real world case application and the technology offered by SAP. The best practices integrated within the system provide students a unique opportunity to learn and appreciate world class business practices.

An important challenge to ERP Systems is to take into account the increasing uncertainty of business environments, especially related to customer demand and vendor reliability. Future course development will stress the planning capability offered by $R / 3$. It will require us to explore the reporting functionality more fully and apply this functionality to performance measures useful in data warehousing. Given this fact the possibility of a graduate level role out using SAP and its more advanced modules such as Customer Relationship Management (CRM) and Strategic Enterprise Management (SEM) is under consideration.

\section{References}

1. AICPA (2000a). "AICPA Core Competency Framework for Entry into the Accounting Profession," http://www.aicpa.org/edu/func.htm. 
2. AICPA Top Ten Technologies Task Force (2000b). "The AICPA Top Ten Technologies for 2000," http://www.toptentechs.com.

3. Albrecht, W. Steve and Robert J. Sack. Accounting Education: Charting the Course through a Perilous Future. Sarasota, FL: American Accounting Association, 2000.

4. Becerra-Fernandez, Irma, Kenneth E. Murphy, and Steven J. Simon. "Integrating ERP in the Business School Curriculum," Communications of the ACM, April 2000, pp. 39-41.

5. Chau, K Y, and Chan, S F. "Implementing ERP through continuous improvement." International Journal of Manufacturing Technology and Management. Geneva: 2002. Vol. 4, Iss. 6; p. 465

6. Federation of Schools of Accountancy (1999). "Recommendations for the Design of Empirical Studies Examining Curricular Efforts to Develop Student Critical Thinking Skills," http://www.thefsa.org/publications/studies.htm.

7. George Joseph, and Asha George. "ERP, learning communities, and curriculum integration" Journal of Information Systems Education, 2002, Vol. 13, Iss 1; pg. 51, 8 pgs

8. Kaveney, Michael. "Syracuse University to Have New ERP Lab," Business Journal 14 (2/18/00), p. 27.

9. Kirby, Horton. "ERP; A bearing on success." Works Management. Nov 2002. Vol. 55, Iss. 11; p. 8

10. Robey, Daniel, Ross, Jeanna W., Boudreau, Marie-Claude. "Learning to implement enterprise systems: An ecploratory study of the dialectics of change." Journal of Management Information Systems. Armonk: Summer 2002. Vol. 19, Iss. 1; p. 17

11. Stedman, Craig. "College ERP Success: May Take Custom Fit," Computerworld 33 (11/29/99), p. 12.

12. Tuteja, Akhilesh. "Enterprise Resource Planning: It Can be Risky," May 1, 2000, http://www.itaudit.org.

13. Volkoff, Olga. "Configuring an ERP system: Introducing best practices or hampering flexibility?" Journal of Information Systems Education. West Lafayette: Fall 2003. Vol. 14, Iss. 3; p. 319

\section{Appendix A}

\begin{tabular}{|c|c|c|c|c|c|}
\hline & $\mathbf{S}$ & $\mathbf{M}$ & $\mathbf{A}$ & $\mathbf{R}$ & $\mathbf{T}$ \\
\hline Purchasing & $\begin{array}{l}\text { Company Code - } 3000 \\
\text { Plant - } 3000 \\
\text { Purchasing Organization - } 3000 \\
\text { Purchasing Group - } 020\end{array}$ & $\begin{array}{l}\text { Vendor Master } \\
\text { Material Master }\end{array}$ & $\begin{array}{l}\text { Purchase Order } \\
\text { Goods Receipt } \\
\text { Invoice } \\
\text { Cash }\end{array}$ & $\begin{array}{l}\text { Purchase } \\
\text { Information } \\
\text { System }\end{array}$ & SPARCLE \\
\hline Production & $\begin{array}{l}\text { Company Code - } 3000 \\
\text { Plant - } 3000 \\
\text { Storage Location - } 0001\end{array}$ & Material Master & $\begin{array}{l}\text { Sales \& Operations } \\
\text { Planning } \\
\text { Master Production } \\
\text { Scheduling } \\
\text { Material Requirements } \\
\text { Planning } \\
\text { Production Planning } \\
\text { Production Control } \\
\text { Product Confirmation } \\
\text { Goods Receipt }\end{array}$ & $\begin{array}{l}\text { Production } \\
\text { Information } \\
\text { System }\end{array}$ & SPARCLE \\
\hline Sales & $\begin{array}{l}\text { Company Code - } 3000 \\
\text { Sales Organization - } 3000 \\
\text { Distribution Channel - } 10 \\
\text { Sales Division - } 00\end{array}$ & $\begin{array}{l}\text { Customer Master } \\
\text { Material Master }\end{array}$ & $\begin{array}{l}\text { Sales order } \\
\text { Transfer order } \\
\text { Picking } \\
\text { Post goods issue } \\
\text { Invoice } \\
\text { Cash }\end{array}$ & $\begin{array}{l}\text { Sales } \\
\text { Information } \\
\text { System }\end{array}$ & SPARCLE \\
\hline
\end{tabular}

